\title{
The Study of Naphthoquinones and Their Complexes with DNA by Using Raman Spectroscopy and Surface Enhanced Raman Spectroscopy: New Insight into Interactions of DNA with Plant Secondary Metabolites
}

\author{
Veronika Vaverkova, ${ }^{1}$ Oldrich Vrana, ${ }^{2}$ Vojtech Adam, ${ }^{3}$ \\ Tomas Pekarek, ${ }^{4}$ Josef Jampilek, ${ }^{5}$ and Petr Babula ${ }^{1}$ \\ ${ }^{1}$ Department of Natural Drugs, Faculty of Pharmacy, University of Veterinary and Pharmaceutical Sciences, Palackeho 1-3, \\ 61242 Brno, Czech Republic \\ ${ }^{2}$ Institute of Biophysics, Academy of Sciences of the Czech Republic, Kralovopolska 135, C612 65 Brno, Czech Republic \\ ${ }^{3}$ Department of Chemistry and Biochemistry, Faculty of Agronomy, Mendel University in Brno, Zemedelska 1, \\ 61300 Brno, Czech Republic \\ ${ }^{4}$ Zentiva, k.s., Development Department, U Kabelovny 130, 10237 Praha 10, Czech Republic \\ ${ }^{5}$ Department of Chemical Drugs, Faculty of Pharmacy, University of Veterinary and Pharmaceutical Sciences, Palackeho 1-3, \\ 61242 Brno, Czech Republic
}

Correspondence should be addressed to Petr Babula; petr-babula@email.cz

Received 16 February 2014; Accepted 21 May 2014; Published 22 June 2014

Academic Editor: Vicky Kett

Copyright ( 2014 Veronika Vaverkova et al. This is an open access article distributed under the Creative Commons Attribution License, which permits unrestricted use, distribution, and reproduction in any medium, provided the original work is properly cited.

\begin{abstract}
Naphthoquinones represent the group of plant secondary metabolites with cytotoxic properties based on their ability to generate reactive oxygen species and interfere with the processes of cell respiration. Due to this fact, the possible cytotoxic mechanisms on cellular and subcellular levels are investigated intensively. There are many targets of cytotoxic action on the cellular level; however, DNA is a critical target of many cytotoxic compounds. Due to the cytotoxic properties of naphthoquinones, it is necessary to study the processes of naphthoquinones, DNA interactions (1,4-naphthoquinone, binapthoquinone, juglone, lawsone, plumbagin), especially by using modern analytical techniques. In our work, the Raman spectroscopy was used to determine the possible binding sites of the naphthoquinones on the DNA and to characterize the bond of naphthoquinone to DNA. Experimental data reveals the relationships between the perturbations of structure-sensitive Raman bands and the types of the naphthoquinones involved. The modification of DNA by the studied naphthoquinones leads to the nonspecific interaction, which causes the transition of B-DNA into A-DNA conformation. The change of the B-conformation of DNA for all measured DNA modified by naphthoquinones except plumbagin is obvious.
\end{abstract}

\section{Introduction}

Naphthoquinones are naturally widespread secondary metabolites, the products of some actinomycetes (Streptomyces Waksman and Henrici), fungi (Fusarium Link, Marasmius Fr., and Verticillium Nees), lichens, algae, and plants. The most important naphthoquinones-containing plants belong to the group of phylogenetically heterogeneous plant families Avicenniaceae Endl. ex Schnizl., Balsaminaceae
DC., Bignoniaceae Juss., Boraginaceae Juss., Droseraceae Salisb., Ebenaceae Gurke, Juglandaceae A. Rich. ex Kunth, Nepenthaceae Dum., and Plumbaginaceae Juss. [1-4]. The chemical structure of the monomeric naphthoquinones is based on the bicyclic system-naphthalene skeleton substituted in the positions $\mathrm{C}_{(1)}$ and $\mathrm{C}_{(4)}$ (1,4-naphthoquinones) or $\mathrm{C}_{(1)}$ and $\mathrm{C}_{(2)}$ (1,2-naphthoquinones). There are dimeric and trimeric naphthoquinones, which evidence significant cytotoxic properties on different tumour cell lines including 
prostate androgen-dependent cell lines, and breast tumour cell lines $[5,6]$. Naphthoquinones have many physiological roles; the most important ubiquitous naphthoquinones are vitamins of the $\mathrm{K}$ group-phylloquinone and menaquinone [7-9]. Plenty of naphthoquinones are important phytoalexins, so they play an important role in ecological relationships [10]. Naphthoquinones have found many possibilities for use-antimicrobial, antifungal, antiviral, and antiprotozoal properties have been identified. In traditional medicines, particularly in Asia (China) and South America, plants with naphthoquinones have a wide range of application, especially in the treatment of various types of cancer [2]. The cytotoxic properties of the naphthoquinones are in the focus of interest of many scientists. They are predominantly based on the ability of naphthoquinones to generate reactive oxygen species (ROS), which are involved in many cellular processes and serve as signal molecules in apoptosis/programmed cell death and are partially responsible for cytotoxic properties demonstrated in many in vitro tumour cell line systems [11-14]. The ability of naphthoquinones to interfere with the respiratory chain poses the second possible cytotoxic mechanism [15-17]. DNA is the critical target of the activity of many compounds including plant secondary metabolites. There is a large group of natural origin compounds with interesting cytotoxic properties. Their cytotoxic effect is based on their interactions with DNA, especially on the possibility of forming various types of covalent adducts with DNA. The most important compounds, whose effect is based on DNA interaction, are anthracyclines, cytotoxic antibiotics, and platinum-based cytostatics [18-21].

DNA-metal and DNA-metal based complexes interactions and their effect on DNA structure are already known [22-29]. Cisplatin as an important and frequently used anticancer drug forms covalent bonds with nucleophilic sites on guanine residues present in DNA. As a cisplatin is a bifunctional agent, it is able to bind to one (monofunctional adduct) or two (intrastrand crosslinks, interstrand crosslinks) places in a DNA chain [30-32]. All of these adducts characteristically distort the DNA conformation $[33,34]$. The main problem in the curing process with many anticancer complexes such as cisplatin is the reduced sensitivity of the tumour towards this drug when the drug is repeated in the treatment. A medical treatment is connected with many inadvisable effects [35, 36]. Therefore, new structures with reduced toxicity, often of natural origin, are intensively searched. Due to significant cytotoxic properties of the selected naphthoquinones (see Figure S1 in Supplementary Material available online at http://dx.doi.org/10.1155/2014/461393), we decided to study the naphthoquinones-DNA interactions as a possible mechanism of their cytotoxicity. In recent years, naphthoquinone derivatives have been intensively studied in connection with their cytotoxic and antibacterial effects and subsequently possible usage in cancer treatment [3741]. Despite the above-mentioned mechanisms of naphthoquinones cytotoxicity, their interactions with DNA have not yet been established. Due to this fact, we focused on the investigation of naphthoquinones-DNA interactions in our work. The identification of the binding sites of naphthoquinones on DNA and the determination of how the binding may affect secondary and tertiary structures is still lacking. Some naphthoquinones have been identified as potent inhibitors of topoisomerases I and II; this activity may contribute to their cytotoxic effect $[2,37,42]$. In addition, newly synthesized complexes of lawsone and metal ions are recently investigated as cytotoxic compounds with the cytotoxic effect based on the DNA interactions [43]. The vibrational spectra [44, 45], optical absorption and fluorescence emission spectra [46, 47], and SERS studies [44, 45, 48-51] of some naphthoquinone derivatives have also been reported. However, the naphthoquinones-DNA interactions can play the crucial role in their cytotoxic effect. The vibrational spectroscopy (Raman spectroscopy) can help making unambiguous identification of vibrational modes of biological molecular systems [24, 32]. We used Raman spectroscopy to assess the binding sites of the naphthoquinones to DNA and to characterize and compare the perturbations of DNA after its modification by naphthoquinones in our work. We used Raman spectroscopy and SERS in the analysis of DNA modified by the selected naphthoquinones: 1,4-naphthoquinone, binaphthoquinone, juglone, lawsone, and plumbagin (Figure S1). The spectra obtained were analyzed and characteristic spectral changes were described with the aim of determining interactions between selected naphthoquinones and DNA and analyzing DNA structural changes under naphthoquinones-DNA interactions. In addition, the linear dichroism spectroscopy was used to verify these results.

\section{Materials and Methods}

2.1. Chemicals, Material and $p H$ Measurements. 1,4-Naphthoquinone, binaphthoquinone [2,2-bi(3-hydroxy-1,4-naphthoquinone], juglone [5-hydroxy-1,4-naphthoquinone], lawsone [2-hydroxy-1,4-naphthoquinone], and plumbagin [5hydroxy-2-methy-1,4-naphthoquinone] as well as all other chemicals of ACS purity unless noted otherwise were purchased from Sigma Aldrich Chemical Corp. (SigmaAldrich, USA). Deionised water underwent demineralization by reverse osmosis by using an instrument Aqua Osmotic 02 (Aqua Osmotic, Tisnov, Czech Republic) and was subsequently purified by using a Millipore RG (Millipore Corp., USA, $18 \mathrm{M}^{\prime} \Omega$ ) - MiliQ water. The $\mathrm{pH}$ value was measured by using the WTW inoLab pH meter (Weilheim, Germany).

2.2. Preparation of DNA. DNA was isolated from the calf thymus in accordance with the published work of Brabec et al. [33]. DNA was dissolved in $0.5 \mathrm{M} \mathrm{NaCl}$ and was then sonicated for 20 minutes by using a Sonicator 3000 (Giltron, USA) and subsequently analyzed. The first step of denatured DNA analysis was the electrophoresis by using the source Standard Power Pack P25 by (Biometra, Germany). The gel was photographed after the backlighting the gel by UV on a transilluminator TVX-20M (312 nm) (AlysLabware, Switzerland). The next step was the polarography on an analyzer EG\&G PARC Model 384B (LabX, Canada). The concentration of DNA was measured on a Beckman DU 7400 (Pall Gelman, Germany). For the dialysis, a Spectra/Por 1214000 (Cole-Palmer, USA) was used. The lyophilization was 
performed on a Labconco 4.5 (LabX, Canada). To remove the proteins, which cause the fluorescence of DNA in Raman spectroscopy, phenol and chloroform extractions were used. The final DNA concentration was $2 \times 10^{-1} \mathrm{M}$.

Naphthoquinones were dissolved in a volume of $3 \mathrm{~mL}$ in the purified Milli-Q water. The final concentrations of the selected naphthoquinones were 1,4-naphthoquinone$3.2 \times 10^{-1} \mathrm{M}$, binaphthoquinone $-3.1 \times 10^{-1} \mathrm{M}$, juglone $-2.9 \times$ $10^{-1} \mathrm{M}$, lawsone $-3.2 \times 10^{-1} \mathrm{M}$, and plumbagin $-2.8 \times 10^{-1} \mathrm{M}$.

2.3. Raman Spectroscopy. Spectra were recorded on the Raman spectrometer, Jobin-Yvon T64000 (Horiba, France).

2.4. Surface-Enhanced Raman Spectroscopy. The preparation of Ag colloid: component A-5.15 mg of hydroxylamine hydrochloride was added to $5 \mathrm{~mL}$ of redistilled water, and component B-6.00 mg of sodium hydroxide was also added to $5 \mathrm{~mL}$ of redistilled water. Both these components were mixed and immediately added to the solution of silver nitrate $(8.48 \mathrm{mg}$ silver nitrate in $45 \mathrm{~mL}$ of redistilled water). The colloid was measured using UV spectroscopy and then compared with previous studies [33, 52, 53]. The silver (Ag) colloid complex (of naphthoquinones) was prepared by mixing equal volumes of the solution of naphthoquinones or DNA with the Ag colloid to obtain the final concentration of $5 \times 10^{-7} \mathrm{M}$ or $5 \times 10^{-6} \mathrm{M}$. The final concentration of the colloid was $9 \times 10^{-4} \mathrm{M}$. The spectra of the prepared samples were measured immediately after mixing the naphthoquinone or DNA with Ag colloid at $25^{\circ} \mathrm{C}$. Samples $(10 \mu \mathrm{L})$ were sealed in a glass capillary. The measurement of the whole spectrum was divided into two parts and each part consisted of several accumulations $(16 \times 2 \mathrm{~s})$.

2.5. Preparation of DNA-Naphthoquinone Complexes. To prepare each naphthoquinone-DNA complex, DNA was incubated with the naphthoquinones in the solution of $0.01 \mathrm{M}$ $\mathrm{NaClO}_{4}$ at $37^{\circ} \mathrm{C}$ in the dark for 24 hours.

2.6. Instrumentation. The complexes (naphthoquinones + DNA) were dissolved to a final concentration of $30 \mathrm{mg} / \mathrm{mL}$ in $0.1 \mathrm{M} \mathrm{NaCl}(\mathrm{pH} 7.0)$. Aliquots $(4 \mu \mathrm{L})$ of such prepared complexes were sealed in a glass capillary Kimax 34507 (Kimble products, USA). Spectra of these aliquots were excited at $488 \mathrm{~nm}$ using an argon ion laser (Innova 90C Fred, Coherent, USA). The radiant power at the sample was set to $100 \mathrm{~mW}$ and it was monitored by a Broadband Power Meter (MellesGriotte, USA). Measurements were performed at $25^{\circ} \mathrm{C}$ in back scattering geometry. Rayleigh line was removed from the scattered light by a Kaiser Optical notch filter. The Raman signal was detected in a single mode using 1200 lines/nm grating, entrance slit of $0.1 \mathrm{~mm}$ wide, and a spectrum One CCD3000 LN2 cooled detector. Spectrometer and detector were controlled by JobinYvonLabSpec software version 3.03t (Horiba, France).

The Raman spectra of individual naphthoquinones used for complexation were measured prior to the colloid spectral analysis. Spectra of these molecules were acquired directly in the solid phase in the same instrumental settings as mentioned above. The laser power was set to $10 \mathrm{~mW}$.

2.7. Data Processing. Some spectra were disturbed by a significant fluorescent background. It was approximated by the polynomial function and subtracted by using "baseline correction" functionality of the LabSpec software. For the normalization of the different spectra, the Raman band near $1092 \mathrm{~cm}^{-1}$ assigned to the phosphate group vibration was used as an internal intensity standard. The intensity of this band remains the same regardless of the A-DNA or B-DNA conformation [54]. The processing of the data measured was carried out by using the LabSpec software (Horiba, France). Spectra were further converted to Omnic 6.2 (Thermo, USA) format.

2.8. Linear Dichroism (LD). LD was used to confirm the intercalation of the naphthoquinones to DNA. LD spectra were recorded by using a flow Cuvette cell in a Jasco J720 spectropolarimeter adapted for LD measurements (Jasco Analytical Instruments, Japan). Long molecules such as DNA can be orientated in the flow Cuvette cell. The flow cell consists of a fixed outer cylinder and a rotating solid quartz inner cylinder, separated by a gap of $0.5 \mathrm{~mm}$, giving a total path length of $1 \mathrm{~mm}$ [55]. LD spectra of ctDNA modified by the selected naphthoquinones were recorded at $25^{\circ} \mathrm{C}$ in $10 \mathrm{mM} \mathrm{NaClO}_{4}$.

\section{Results}

3.1. Control of DNA Denaturation. DNA was sonicated and the possible denaturation of DNA was checked (see Supplementary Material).

3.2. Raman Spectra of DNA Modified by Selected Naphthoquinones (Solid Phase, Solutions). The overview of the selected naphthoquinones' Raman spectra is given in Figure S3. These spectra are used further for the evaluation of the Raman spectra of the colloid-DNA complexes in the following chapters.

3.3. The Analysis of DNA Modified by 1,4-Naphthoquinone. We used the main bands in the spectra for the comparison of the changes in the cases of the modified DNA by selected naphthoquinones. These bands are used for description of interaction in cases of different compounds [1, 31, 45, 5659]. Only the most important spectral features are discussed in the following chapters; particular bands assignment is present in Table 2. The bands near 670 and $683 \mathrm{~cm}^{-1}$ are a marker of $\mathrm{C}^{\prime}$-endo/anti-conformation in case of A-form DNA (A-DNA). The intensity of the band near $670 \mathrm{~cm}^{-1}$ decreases together with the conformation of the sugar part of deoxyriboguanosine conversion from $\mathrm{C}_{2}^{\prime}$-endo/anticonformation to $\mathrm{C} 3^{\prime}$-endo conformation [31, 60-62]. The ratio of bands' intensities $683 / 669 \mathrm{~cm}^{-1}>1$ indicates that the DNA modified by the complex is in the B-conformation. Higher intensity of the band at $669 \mathrm{~cm}^{-1}$, the higher the portion of the modified DNA in the A-form. Thus, the final 


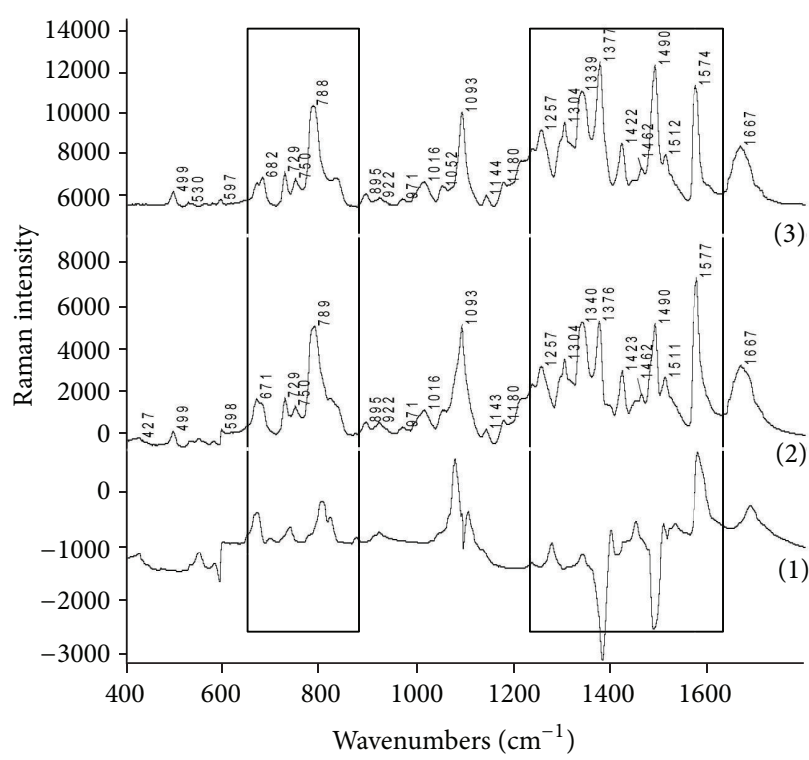

(a)

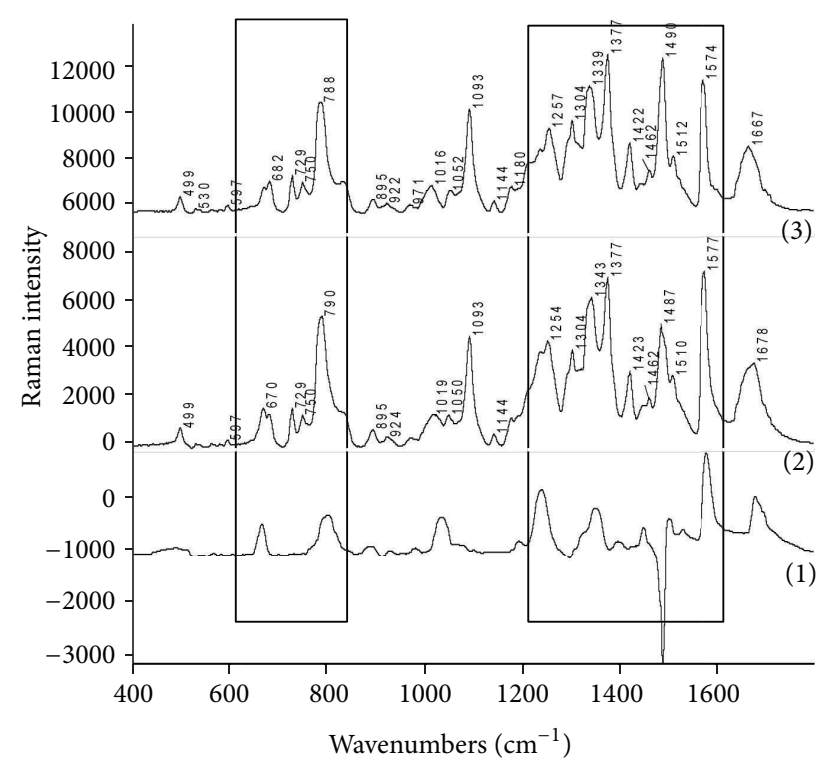

(b)

FIGURE 1: Raman spectra (a): (1) difference Raman spectrum of DNA and 1,4-naphthoquinone (spectrum 2-spectrum 3), (2) Raman spectrum of DNA and 1,4-naphthoquinone, and (3) control ctDNA (the areas with the differences in spectra are in the border), (b): (1) difference Raman spectrum of DNA and binaphthoquinone (spectrum 2-spectrum 3), (2) Raman spectrum of DNA and binaphthoquinone, and (3) control ctDNA (the areas with the differences in spectra are in the border).

ratio of the bands' intensities $683 / 669 \mathrm{~cm}^{-1}<1$ proves the Aconformation of the modified DNA by 1,4-naphthoquinone (Figure 1(a)). There is not an intensive band at $834 \mathrm{~cm}^{-1}$ in DNA modified by 1,4-naphthoquinone and this fact supports the assumption of the transition from B-DNA to A-DNA. The increase of the band at $804 \mathrm{~cm}^{-1}$ in DNA modified by 1,4-naphthoquinone indicates the local structural changes and it is the next evidence of A-form presence. The band at $788 \mathrm{~cm}^{-1}$ in the DNA is a combination band of cytosine, thymine, and the phosphodiester band. This band is therefore very intensive also in the modified DNA. The bands of DNA (modified and unmodified) in the region $800-1050 \mathrm{~cm}^{-1}$ correspond to the vibrations of the sugar-phosphate backbone skeleton. The intensity change of the band near $1078 \mathrm{~cm}^{-1}$ is influenced by the contribution of 1,4-naphthoquinone (Figure 1(a)). The band at $1340 \mathrm{~cm}^{-1}$ corresponds to the vibration of adenine and guanine. Changes of the intensity of this band indicate changes in the pairing between GC and AT bases. In the DNA modified by 1,4-naphthoquinone stacking interaction was interrupted and 1,4-naphthoquinone was fastened onto adenine in DNA structure. The band at $1377 \mathrm{~cm}^{-1}$ in the spectrum of DNA modified by 1,4naphthoquinone is influenced by the thymine vibration. Due to changes of adenine-thymine pairing the intensity of this band is changed in the modified DNA spectrum compared to native DNA. The band $1504 \mathrm{~cm}^{-1}$ (in B-DNA is located in the area of $1511 \mathrm{~cm}^{-1}$ ) in DNA modified by 1,4-naphthoquinone is assigned to the vibration of imidazole ring of adenine and the increasing intensity of this band indicates a partial modification of adenine and guanine. The band in DNA modified by 1,4-naphthoquinone near $1574 \mathrm{~cm}^{-1}$ corresponds to the overlapping contributions from the $\mathrm{dG}$ and $\mathrm{dA}$. This band is located at $1577 \mathrm{~cm}^{-1}$, in the spectrum of B-DNA. The increasing intensity of this band in the case of DNA modification by 1,4-naphthoquinone results in disruption of hydrogen bonds in GC and AT pairs. This fact is related with the predenaturation and denaturation changes in DNA modified by 1,4-naphthoquinone. The band at $1688 \mathrm{~cm}^{-1}$ corresponds to the carbonyl group stretching vibration of the $(\mathrm{C}=\mathrm{O})$ group of the thymine and its width is influenced by the hydrogen bonds of thymine and adenine.

3.4. Analysis of DNA Modified by Binaphthoquinone. The ratio of intensities at $683 / 670 \mathrm{~cm}^{-1}$ is 0.7 which indicates the transition from the $\mathrm{B}$-conformation in A-conformation (Table 3) in the spectrum of DNA modified by binaphthoquinone (Figure 1(b)) like in the case of DNA modified by 1,4-naphthoquinone. Furthermore, changes in the DNA modified by binaphthoquinone in the intensity of the band at $804 \mathrm{~cm}^{-1}$ are observed. This is in concordance with changes from the $\mathrm{B}$-conformation $\left(834 \mathrm{~cm}^{-1}\right)$ into the Aconformation $\left(807 \mathrm{~cm}^{-1}\right)$ and this change coincides with an increase in the intensity of band $670 \mathrm{~cm}^{-1}$. The band at $1339 \mathrm{~cm}^{-1}$ in the spectrum of native DNA is a combination band of adenine, guanine, and thymine. In the spectrum of DNA modified by binaphthoquinone this band indicates high distorsions in AT and GC base pairs and large local denatruration was obvious and the large local denaturation was obvious.

3.5. Analysis of DNA Modified by Juglone. DNA modified by juglone was changed in the areas around $670 \mathrm{~cm}^{-1}$ and $683 \mathrm{~cm}^{-1}$ compared to the native DNA. The ratio of the bands' 


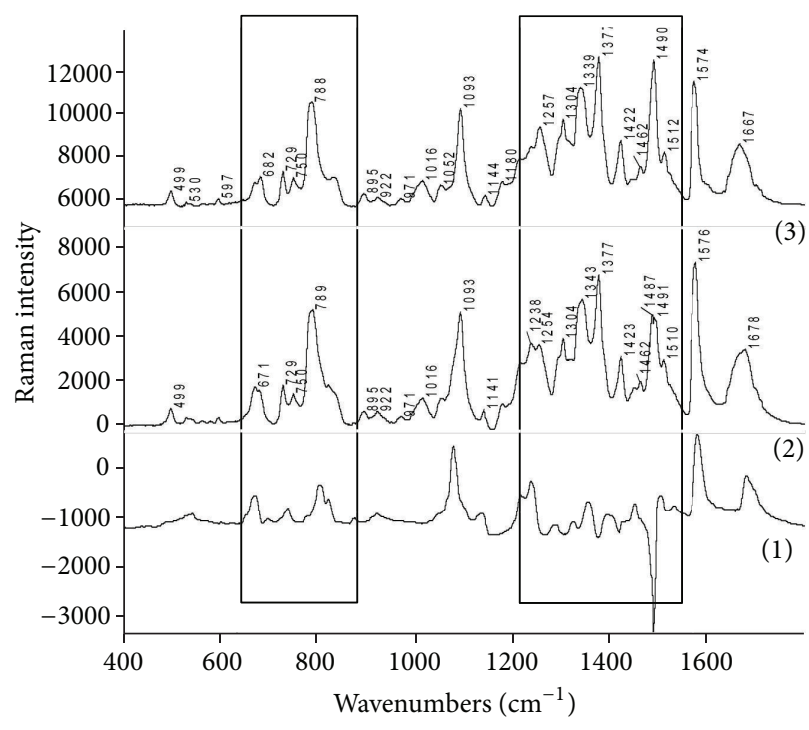

(a)

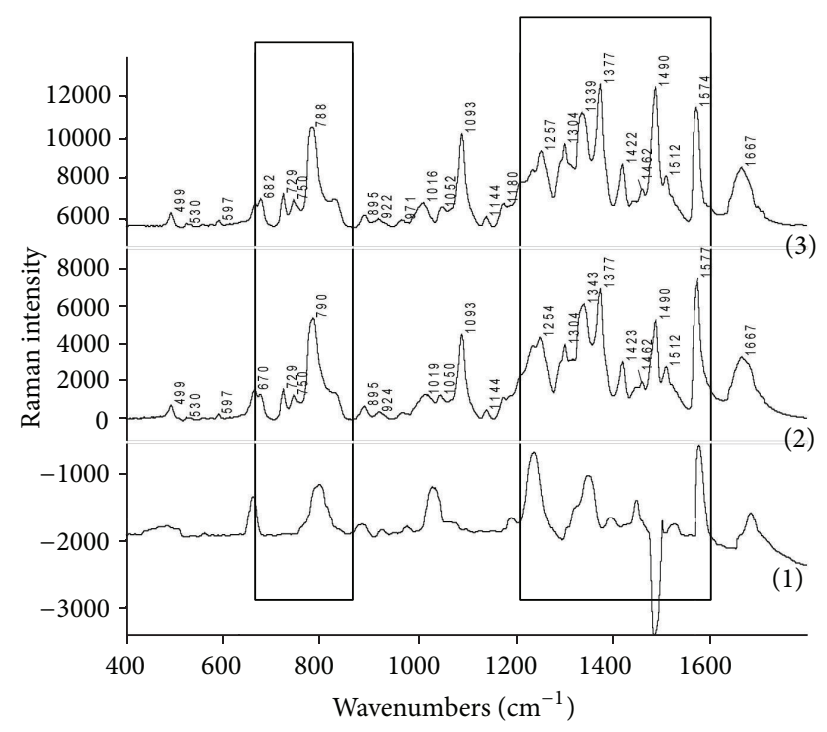

(b)

FIGURE 2: Raman spectra (a): (1) difference Raman spectrum of DNA and juglone (spectrum 2-spectrum 3), (2) Raman spectrum of DNA and juglone, and (3) control ctDNA (the areas with the differences in spectra are in the border), (b): (1) difference Raman spectrum of DNA and lawsone (spectrum 2-spectrum 3), (2) Raman spectrum of DNA and lawsone, and (3) control ctDNA (the areas with the differences in spectra are in the border).

intensities $683 / 670 \mathrm{~cm}^{-1}$ is 0.9 (Table 3), which indicates the transition from the B-conformation in A-conformation (Figure 2(a)) as it was in the case of DNA modified by 1,4-naphthoquinone and binaphthoquinone. This fact is also supported by the highest increasing intensity of the band at $807 \mathrm{~cm}^{-1}$ in the case of DNA modified by juglone. The band at $1237 \mathrm{~cm}^{-1}$ represents the vibrations of cytosine and thymine in the native DNA, and its increase in the case of DNA modified by juglone corresponds to the local denaturation. In DNA modified by juglone the increase of intensity near $1343 \mathrm{~cm}^{-1}$ is related to the changes in the deoxyribonucleoside conformation in the GC and AT pairs, which is significant for the local denaturation (as well as the band at $1237 \mathrm{~cm}^{-1}$ ). In the difference Raman spectrum of DNA modified by juglone the increase of the band at $1503 \mathrm{~cm}^{-1}$ is clearly observable; this intensity change is related to the hydrogen bond of adenine and thymine. This means that the AT hydrogen bonds have been broken and juglone was fastened to the adenine in the DNA structure.

3.6. Analysis of DNA Modified by Lawsone. From the difference Raman spectrum of DNA modified by lawsone it is clear that there are changes in the areas near $670 \mathrm{~cm}^{-1}$ and near $683 \mathrm{~cm}^{-1}$ (Figure 2(b)). In the DNA modified by lawsone the intensity of the band at $670 \mathrm{~cm}^{-1}$ increased more than the intensity of the band near $683 \mathrm{~cm}^{-1}$. The ratio of bands' intensities at $683 / 670 \mathrm{~cm}^{-1}$ is 0.7 (Table 3), which indicates the transition from the B-conformation of native DNA to Aconformation of the modified DNA, similarly to DNA modified 1,4-naphthoquinone, binaphthoquinone, and juglone.
We also identified changes in the spectra of DNA modified by lawsone near $807 \mathrm{~cm}^{-1}$, which also indicates changes from Bconformation $\left(834 \mathrm{~cm}^{-1}\right)$ in the A-conformation $\left(807 \mathrm{~cm}^{-1}\right)$ and this change coincides with an increase in the intensity of band at $670 \mathrm{~cm}^{-1}$. The band at $1343 \mathrm{~cm}^{-1}$ is slightly shifted in DNA modified by lawsone comparing to native DNA and it corresponds to the vibrations of adenine, guanine, and thymine. There have been high distortions in AT and GC base pairs and therefore there was a large local denaturation in AT and GC base pairs. In DNA modified by lawsone the band at $1577 \mathrm{~cm}^{-1}$ increased its intensity by more than $18 \%$ than in the case of DNA modified by 1,4-naphthoquinone and binaphthoquinone. This change indicates much more noticeable disruption of the hydrogen bonds in GC and TA pairs (similar to the band at $1338 \mathrm{~cm}^{-1}$ ) and greater predenaturation and denaturation effects than if it was in the case of DNA modified by 1,4-naphthoquinone and binaphthoquinone.

3.7. Analysis of DNA Modified by Plumbagin. From the Raman spectra of DNA modified by plumbagin it is obvious that modified DNA was not transformed in the areas around $670 \mathrm{~cm}^{-1}$ and $683 \mathrm{~cm}^{-1}$ (Figure 3(a)). The ratio of the bands' intensities $683 / 670 \mathrm{~cm}^{-1}$ is 1.3 (Table 3 ), which does not indicate the transition from the B-conformation DNA in A-conformation. In DNA modified by plumbagin the band at $1236 \mathrm{~cm}^{-1}$ corresponds to vibrations of cytosine and thymine, and in this area the local denaturation is obvious. There were some denaturation changes in the DNA structure when modified by plumbagin but these changes do not inevitably indicate that plumbagin was intercalated into DNA. 


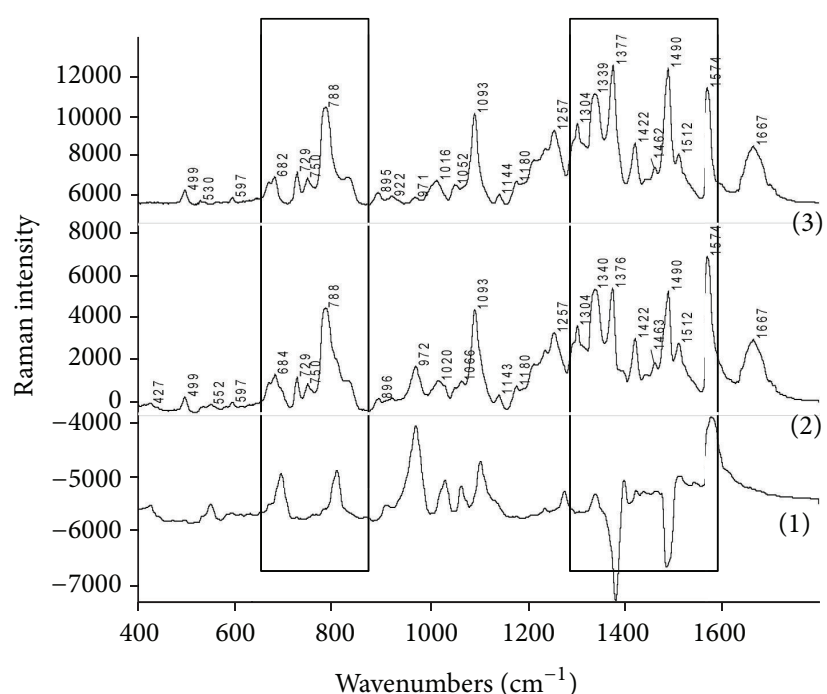

(a)

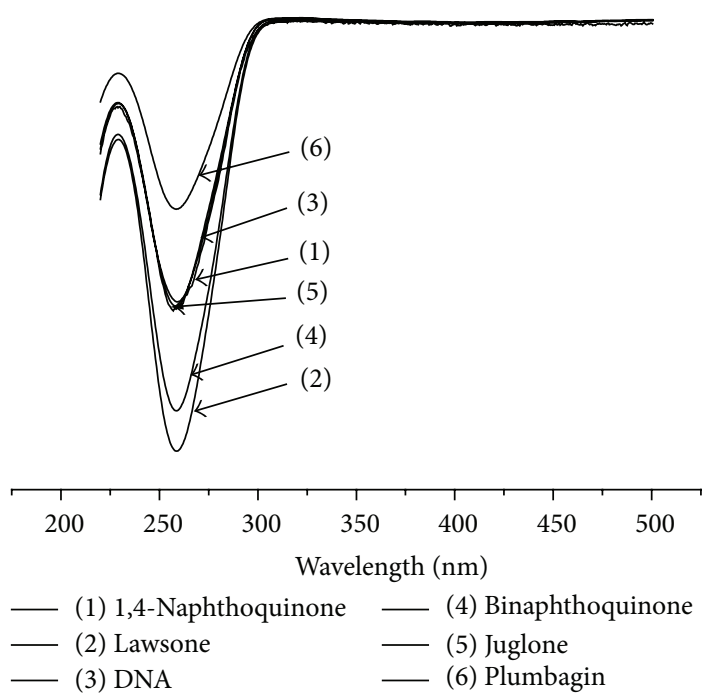

(b)

Figure 3: (a): Raman spectra (1) difference Raman spectrum of DNA and plumbagin (spectrum 2-spectrum 3), (2) Raman spectrum of DNA and plumbagin, and (3) control ctDNA (the areas with the differences in spectra are in the border), (b) linear dichroism (LD) spectra of calf thymus DNA modified by (1) 1,4-naphthoquinone, (2) lawsone, (3) control, nonmodified DNA, (4) binaphthoquinone, (5) juglone, and (6) plumbagin.

TABLE 1: The increase (decrease) of the bands in the Raman spectrum of DNA after the modification by the studied naphthoquinones. The changes are expressed in the percentages $\left({ }^{*}\right.$ the observation of Raman intensity of calf thymus DNA represents $100 \%$; the change is counted separately for each band).

\begin{tabular}{|c|c|c|c|c|c|c|}
\hline DNA-naphthoquinone & $\mathrm{DNA}^{*}$ & 1,4-Naphthoquinone & Binaphthoquinone & Juglone & Lawsone & Plumbagin \\
\hline $670 \mathrm{~cm}^{-1}$ vibrations of thymine & 100 & 181 & 191 & 190 & 186 & 95 \\
\hline $683 \mathrm{~cm}^{-1}$ vibrations of guanine & 100 & 112 & 101 & 118 & 101 & 120 \\
\hline $834 \mathrm{~cm}^{-1} \mathrm{~B}$-conformation, phosphodiester bond & 100 & 96 & 98 & 98 & 98 & 99 \\
\hline $1237 \mathrm{~cm}^{-1}$ vibrations of cytosine and thymine & 100 & 85 & 147 & 129 & 144 & 102 \\
\hline $1256 \mathrm{~cm}^{-1}$ vibrations of cytosine and thymine & 100 & 81 & 116 & 95 & 113 & 100 \\
\hline $1338 \mathrm{~cm}^{-1}$ vibrations of adenine and guanine & 100 & 102 & 115 & 97 & 114 & 105 \\
\hline $1376 \mathrm{~cm}^{-1}$ vibrations of thymine & 100 & 78 & 109 & 101 & 107 & 86 \\
\hline $1511 \mathrm{~cm}^{-1}$ vibrations of adenine & 100 & 108 & 118 & 119 & 116 & 116 \\
\hline $1578 \mathrm{~cm}^{-1}$ vibrations of adenine and guanine & 100 & 125 & 126 & 123 & 125 & 123 \\
\hline
\end{tabular}

3.8. Results Summary of All Measured Raman Spectra of DNA Modified by Selected Naphthoquinones (Solid Phase, Solutions). The results obtained by Raman spectroscopy were compared with previously published studies where the DNA interactions with some substances were studied $[31,54,60,62-74]$. The increase (decrease) of the selected bands intensity in the Raman spectrum of DNA after modification by the studied naphthoquinones is summarized in Table 1 . All the changes of the Raman band positions and intensities after the modification of DNA by the selected naphthoquinones are introduced in Table 2. Table 3 shows changes in DNA conformation after its modification by naphthoquinones. It is obvious that after modification of DNA by all complexes, DNA was changed from Bconformation to A-conformation except of DNA modified by plumbagin.
3.9. Summary Results of All the Measured SERS Spectra of DNA Modified by Selected Naphthoquinones. The SERS method was used to confirm the hypothesis that substances bind to DNA and to confirm which main bases are modified after this binding to DNA (see Supplementary Material).

3.10. Linear Dichroism Spectroscopy. Long molecules such as DNA show a signal in the LD spectra (if it is oriented specifically). Small unbound molecules show no signal. The intensity of the LD signal of DNA modified by binaphthoquinone and lawsone had been decreased in the area of $260 \mathrm{~nm}$. A smaller decrease in this intensity of LD signal was observed in the case of DNA modified by juglone and 1,4-naphthoquinone and the lowest decrease in intensity of LD signal in the case of DNA modified by plumbagin. 
TABLE 2: The changes of the Raman intensities after the modification of DNA by the selected naphthoquinones: w-weak, m-medium, s-strong, sh-shoulder, br-broad, as-asymmetric.

\begin{tabular}{|c|c|c|c|c|c|c|}
\hline Peak $\left(\mathrm{cm}^{-1}\right)$ & Assignment & 1,4-Naphthoquinone & Binaphthoquinone & Juglone & Lawsone & Plumbagin \\
\hline 670 & $\mathrm{dT}, \mathrm{dA}$ & $670 \mathrm{~m}$ & $667 \mathrm{~m}$ & $667 \mathrm{~m}$ & $667 \mathrm{~m}$ & $667 \mathrm{w}$ \\
\hline 683 & $\mathrm{dG}$ & - & - & - & - & - \\
\hline 729 & A & - & - & - & - & - \\
\hline 750 & $\mathrm{dT}$ & $740 \mathrm{w}$ & - & $741 \mathrm{w}$ & - & - \\
\hline 787 & bk O-P-O str. + dT & $805 \mathrm{~m}$ & $804 \mathrm{~m}, \mathrm{br}$ & $807 \mathrm{~m}, \mathrm{br}$ & $807 \mathrm{~m}$ & $807 \mathrm{~m}$ \\
\hline 834 & bk O-P-O B-DNA & $827 \mathrm{w}$ & - & $821 \mathrm{w}$ & - & - \\
\hline 894 & $\mathrm{dr}, \mathrm{C} 2^{\prime} \mathrm{H}_{2}$ rock & - & - & - & - & - \\
\hline 922 & $\mathrm{dr}$, ring str. & - & - & - & - & $916 \mathrm{~m}$ \\
\hline 970 & $\mathrm{~T} \mathrm{C}_{6} \mathrm{H}$ op-def, bk & - & - & - & - & - \\
\hline 1014 & $\mathrm{~T} \mathrm{CH}_{3}$ rock & - & - & - & - & $1018 \mathrm{sh}$ \\
\hline 1054 & bk C-O str. & $1079 \mathrm{~m}-\mathrm{s}$ & $1038 \mathrm{~m}, \mathrm{br}$ & $1076 \mathrm{~m}-\mathrm{s}$ & $1039 \mathrm{~m}, \mathrm{br}$ & $1073 \mathrm{~s}, \mathrm{br}$ \\
\hline 1093 & POsym., str. & $1110 \mathrm{w}$ & - & - & - & - \\
\hline 1143 & $\mathrm{dT}$ & - & - & $1142 \mathrm{w}$ & - & $1147 \mathrm{~m}$ \\
\hline 1178 & $\mathrm{dT}, \mathrm{dG}, \mathrm{dC}$ & - & - & - & - & $1176 \mathrm{w}$ \\
\hline 1217 & $\mathrm{dT}, \mathrm{dA}, \mathrm{dG}$ & - & - & $1215 \mathrm{sh}$ & - & $1216 \mathrm{~m}$, as \\
\hline 1237 & $\mathrm{dT}, \mathrm{dC}$ & - & 1239 m-s, br & $1237 \mathrm{~m}$ & $1240 \mathrm{~m}, \mathrm{br}$ & - \\
\hline 1256 & $\mathrm{dC}, \mathrm{dA}, \mathrm{dT}(\mathrm{dG})$ & - & - & - & - & - \\
\hline 1307 & $\mathrm{dA}, \mathrm{dT}$ & - & - & $1281 \mathrm{w}$ & $1304 \mathrm{w}$ & - \\
\hline 1338 & $\mathrm{dA}, \mathrm{dG}$ & - & - & $1323 \mathrm{w}$ & $1322 \mathrm{sh}$ & - \\
\hline 1376 & $\mathrm{~T}, \mathrm{CH}_{3} \mathrm{def}$ & $1377 \mathrm{~s}, 1398 \mathrm{w}$ & $1350 \mathrm{~m}, \mathrm{br}$ & $1359 \mathrm{~m}$ & $1355 \mathrm{~m}, \mathrm{br}$ & $1384 \mathrm{w}$ \\
\hline 1421 & $\mathrm{dr} \mathrm{C} 5^{\prime} \mathrm{H}_{2} \mathrm{def}$ & - & - & - & - & - \\
\hline 1446 & & $1448 \mathrm{w}$ & $1452 \mathrm{w}$ & $1448 \mathrm{w}$ & $1448 \mathrm{w}$ & $1442 \mathrm{w}$ \\
\hline 1462 & & - & - & - & - & - \\
\hline 1490 & $\mathrm{G}$ im. ring, $\mathrm{dA}, \mathrm{dT}$ & $1490 \mathrm{~s}$, as & $1490 \mathrm{~s}$ & $1490 \mathrm{~s}$ & $1490 \mathrm{~s}$, as & $1490 \mathrm{~s}$ \\
\hline 1511 & & $1509 \mathrm{w}$ & $1502 \mathrm{w}$ & $1502 \mathrm{w}$ & $1503 \mathrm{w}, \mathrm{sh}$ & $1507 \mathrm{~m}$ \\
\hline 1578 & $\mathrm{dG}, \mathrm{dA}$ & $1574 \mathrm{~s}$, as & $1578 \mathrm{~s}$, as & $1578 \mathrm{~s}$, as & 1579 s, as & $1576 \mathrm{~s}$ \\
\hline 1669 & $\mathrm{~T}, \mathrm{dG}$ & $1688 \mathrm{w}$ & $1688 \mathrm{~m}$, as & $1685 \mathrm{~m}$, as & $1689 \mathrm{w}, \mathrm{br}$ & $1680 \mathrm{~m}-\mathrm{s}, \mathrm{br}$, as \\
\hline
\end{tabular}

TABLE 3: The ratio of the size of the peak intensities at $683 / 670 \mathrm{~cm}^{-1}$ with a peak intensity of $683 \mathrm{~cm}^{-1}$.

\begin{tabular}{lc}
\hline DNA-naphthoquinone & $683 / 670 \mathrm{~cm}^{-1}$ \\
\hline 1,4-Naphthoquinone & 0.8 \\
Binaphthoquinone & 0.7 \\
Juglone & 0.9 \\
Lawsone & 0.7 \\
Plumbagin & 1.3 \\
\hline
\end{tabular}

This decreasing intensity of the peak $260 \mathrm{~nm}$ means the intercalation of the studied naphthoquinones into DNA. The decreases of the intensities of the LD band (220-300 nm) confirm that DNA modified by all studied naphthoquinones is shifted from B-DNA to A-DNA [55]. The largest intercalation mode of naphthoquinone to DNA is observed in the case of DNA modified by binaphthoquinone and lawsone, where the decrease of LD band at $260 \mathrm{~nm}$ is the most significant and the molecule of DNA by this modification is the most rigid. The results measured on the LD spectroscopy confirm the assumption that all the selected naphthoquinones intercalate into DNA in the range of lawsone $>$ binaphthoquinone $>$ juglone $>1,4$-naphthoquinone $>$ plumbagin (Figure 3(b)).

\section{Discussion}

It was necessary to reflect on the dramatic changes and to compare these changes in the cases of the modified DNA by 1,4-naphthoquinone, binaphthoquinone, juglone, lawsone, and plumbagin. We use the main bands in the spectra for these comparisons. These bands are widely used for description of interaction in cases of different compounds with DNA $[1,31,45,56-59]$. The bands at $670 \mathrm{~cm}^{-1}$ and $683 \mathrm{~cm}^{-1}$ are markers of A or B-conformation in DNA. These two peaks are associated with the vibration of deoxynucleosides dT (mainly $\left.670 \pm 3 \mathrm{~cm}^{-1}\right)$ and dG $\left(683 \mathrm{~cm}^{-1}\right)$. These markers are used in the studies of interactions between proteins and DNA [75]. Changes in the band near $670 \mathrm{~cm}^{-1}$ indicate the changes in A-/B-DNA conformation (see Table 3 ). However, they cannot be interpreted independently but in the comparison of the changes of the intensities of the band at $683 \mathrm{~cm}^{-1}$. The band near $670 \mathrm{~cm}^{-1}$ is a marker of $\mathrm{C}^{\prime}$-endo/anti-conformation in case of A-form DNA, and in the B-form it is primarily due to 
dT. Decrease of the intensity of this peak is observed when conformation of the sugar moiety of deoxyriboguanosine is converted from $\mathrm{C} 2{ }^{\prime}$-endo/anti-conformation to $\mathrm{C} 3^{\prime}$-endo conformation $[31,60,61]$. It is important to note that Raman band near $660-685 \mathrm{~cm}^{-1}$ is also sensitive to the sugar pucker and glycosyl torsion of deoxyguanosine nucleoside residues $[31,60,61]$. The signals in the area $800-1100 \mathrm{~cm}^{-1}$ are markers of changes in backbone geometry and DNA secondary structure [54]. All the selected naphthoquinones are responsible for the transition of DNA from B to A conformation except the DNA modified by plumbagin. The band at $807 \pm 6 \mathrm{~cm}^{-1}$ is in the A-conformation DNA (A-form DNA phosphodiester marker) counterpart of the intensive band $834 \mathrm{~cm}^{-1}$ in $\mathrm{B}-$ conformation (phosphodiester B-form marker) [54]. The band $807 \mathrm{~cm}^{-1}$ is thus the marker of A-conformation (if the nucleoside conformation does not remain in the $\mathrm{C}^{\prime}$ endo conformation) and its intensity increased the most for DNA modified by binaphthoquinone and plumbagin. By contrast, the intensity increased less for DNA modified by 1,4-naphthoquinone, juglone, and lawsone The band at $834 \mathrm{~cm}^{-1}$ is located in the area of $800-1000 \mathrm{~cm}^{-1}$. Bands in this area are sensitive to changes in the secondary structure of DNA and the changes in the sugar-phosphate backbone skeleton. The band at $834 \mathrm{~cm}^{-1}$ is one of the characteristic markers of B-DNA conformation and the corresponding vibration of the phosphodiester links [45, 76-78]. In the Aconformation of DNA, this band is shifted to lower values to the area from 807 to $811 \mathrm{~cm}^{-1}$, as already was mentioned. In the spectrum of modified DNA by 1,4-naphthoquinone and plumbagin, this band is slightly lower than in the comparison in the spectrum of the DNA modified by binaphthoquinone, juglone, and lawsone which is in good agreement with the data above-mentioned. The band at $1073 \mathrm{~cm}^{-1}$ is partly related to the vibration of the sugar-phosphate backbone (probably electrostatic interaction of the phosphate group) [79-82], but it especially corresponds with the vibrations to the contribution of the naphthoquinones measured in the solid phase-in the case of juglone and plumbagin. The area of band near $1237 \mathrm{~cm}^{-1}\left(1100-1400 \mathrm{~cm}^{-1}\right)$ is in the spectrum of a very rich DNA. The changes in the area of $1200-1600 \mathrm{~cm}^{-1}$ correspond mostly to the changes of the vibration of purine and pyrimidine, so the bands in this area are associated with changes in the structure of the aromatic ring of purine and pyrimidine, which are sensitive to the binding of metal atoms to the aromatic $[60,65,83]$. Intensity of the band at $1237 \mathrm{~cm}^{-1}$, which is related to the vibration of thymine and cytosine, increased mostly for DNA modified by juglone (129\% of control) and lawsone (144\% of control). The significant increase of the intensity of the band results is the contribution of the cytosine and thymine vibration in DNA; it is associated with the bond of the studied naphthoquinones on the DNA and is a significant feature of the local denaturation. Band at $1237 \mathrm{~cm}^{-1}$ was not used only for description of in vitro systems, but also in systems represented by the cell lines [84]. The vibrational mode at $1338 \mathrm{~cm}^{-1}$ is assigned to the vibration of adenine and guanine and signified the local denaturation in AT and GC base pairs [85]. On the other hand, this band indicates formation of triple helices [86]. The band is sensitive to the changes in the electron structure of aromatic ring of purine and pyrimidine. In the case of DNA modification by 1,4-naphthoquinone there is a slight increase in the peak affected by 1,4-naphthoquinone contribution measured in the solid phase and this contribution is predominated by the conformation changes in GC and AT pairs. The significant increase in this peak was observed also for DNA modified by binaphthoquinone and lawsone. In contrast to this, only a small decrease of $1338 \mathrm{~cm}^{-1}$ was observed in the DNA modified by juglone. This result indicates the role of substitution of the naphthoquinone skeleton by hydroxyl groups. The bands at $1376 \mathrm{~cm}^{-1}$ and $1352 \mathrm{~cm}^{-1}$ confirm the local denaturation and they are related to the vibration of thymine, especially its methyl group [80, 87-89]. The band near $1376 \mathrm{~cm}^{-1}$ is linked in the case of DNA modified by binaphthoquinone, juglone, lawsone, and plumbagin with the contribution of these complexes measured in the solid phase. It can be explained that in the case of DNA modified by these naphthoquinones the band intensity increased not only by the contribution of the local denaturation but also by the contribution of these complexes themselves. The change of the band at $1490 \mathrm{~cm}^{-1}$ is assigned to the vibration of guanine and especially adenine $[62,90,91]$. Changes in the difference Raman spectra of this signal were observed for the DNA modified by all studied naphthoquinones. When there is the obvious decrease in the difference Raman spectrum in this area, it is related to the modification of $\mathrm{N}_{(7)}$ guanine. The $\mathrm{N}_{(7)}$ site of guanine is recognized as an important site of the identification of some metal interaction with DNA [92]. The size of the band at $1490 \mathrm{~cm}^{-1}$ decreases after electrophile binding agents to the $\mathrm{N}_{(7)}$. After the modification of DNA by selected naphthoquinones, this decrease is related with the guanine vibration not with the metal interaction with DNA.

The band at $1511 \pm 4 \mathrm{~cm}^{-1}$ is the vibration mode of the imidazole's ring of adenine, particularly adenine stretching vibration [93]. This band intensity increased and it is slightly shifted in case of DNA modification by 1,4-naphthoquinone, binaphthoquinone, juglone, lawsone, and plumbagin. These changes indicate the significant disruption of the hydrogen bonds between adenine and thymine. Similar results are shown in the work of Iyandurai and Sarojini, who focused on the interactions between spermine and DNA [93]. Moreover, in the case of DNA modified by the selected naphthoquinones the band intensity at $1537 \mathrm{~cm}^{-1}$ increased. This is linked to the aromatic ring vibration of cytosine (in the B-conformation of DNA this band is in the area $1531 \mathrm{~cm}^{-1}$ ) and this change therefore well coincides with the changes from B-DNA to A-DNA. The characteristic point of the difference spectrum of DNA modified by all the naphthoquinones studied is the decrease and subsequent increase in the intensity at $1578 \pm$ $4 \mathrm{~cm}^{-1}$ and $1586 \pm 4 \mathrm{~cm}^{-1}$, respectively. Both of these bands are related to the vibration of adenine and guanine. The significant increase of the band intensity at $1578 \pm 4 \mathrm{~cm}^{-1} \mathrm{can}$ be interpreted as a pronounced disruption of the hydrogen bonds in GC and TA pairs. Similar results have been established for the investigation of alive and dead cells (MLE-12 cell line), where dead cells demonstrated significant increase 
of this peak [94]. This fact is related to the predenaturation and denaturation effect occurring in DNA modified by all measured naphthoquinones. The band at $1578 \mathrm{~cm}^{-1}$ increased the most in the case of DNA modified by binaphthoquinone. This change indicates very high disruption of the hydrogen bonds in GC and TA pairs and large predenaturation and denaturation effects in DNA modified by binaphthoquinone. The opposite results were demonstrated in the case of paclitaxel and 5-fluorouracil, where significant decrease of band near $1578 \mathrm{~cm}^{-1}$ was detectable $[85,95]$. On the other hand, these two studies were carried out on the individual tumour cells. From the changes mentioned above it is clear that all the measured naphthoquinones except plumbagin transfer DNA from B-conformation to A-conformation. In the case of DNA modified by plumbagin, some local denaturation changes were observed; thus some interactions between DNA and plumbagin take place but it is not obvious if plumbagin intercalated into DNA. By using SERS and LD spectroscopy the interaction was confirmed. In the SERS spectra the changes of the spectra included changes in the intensities and in the positions of the bands too. This analysis demonstrates that naphthoquinones bind specifically to DNA and cause a specific distortion in the DNA.

\section{Conclusions}

All the studied DNA modifications by the selected naphthoquinones induced changes in the spectral part, which corresponds to the vibration of the sugar-phosphate backbone, in the areas of vibration of the bases, and also in the areas of vibration of each naphthoquinone. The modification of DNA by the studied naphthoquinones leads to the nonspecific interaction, which causes the distortion of DNA, from Bconformation of DNA to A-conformation. The change of the B-conformation of DNA for all measured DNA modified by naphthoquinones except plumbagin is obvious. It is also evident from the SERS spectra that the interaction between DNA and complexes takes places at the bases and not at the sugar-phosphate backbone. In the case of modification of the bases, the adenine and thymine were modified in all DNA modified by naphthoquinones. The area around $1200 \pm 5 \mathrm{~cm}^{-1}$ was affected by the local denaturation. The area around $1600 \pm 5 \mathrm{~cm}^{-1}$ exhibits no significant changes. For each DNA modified by all studied complexes the intensity of the band near $1277 \mathrm{~cm}^{-1}$ increased, which is affected by the vibration of adenine and guanine. It is obvious from these results that all naphthoquinones are bound to DNA except of plumbagin. In the case of plumbagin there were only some denaturation effects after the modification of DNA due to the methyl group in the naphthalene skeleton. The analysis of the difference spectra leads to the clear conclusions that bases have been modified, and these changes have predenaturation and denaturation character. Nevertheless, the results demonstrate that naphthoquinones bind specifically to DNA and cause a specific distortion. The cytotoxic activity of some naphthoquinones may be clarified in this way.

\section{Abbreviations}

$\begin{array}{ll}\text { A-DNA: } & \begin{array}{l}\text { Right-handed double helix, shorter } \\ \text { more compact helical structure }\end{array} \\ \text { B-DNA: } & \text { Right-handed double helix } \\ \text { bp: } & \text { Base pair } \\ \text { bk: } & \text { Backbone } \\ \text { Cisplatina, cis DDP: } & \text { cis- }\left[\left(\mathrm{NH}_{3}\right)_{2} \mathrm{Cl}_{2} \mathrm{Pt}\right] \\ \text { ct DNA: } & \text { Thyme DNA } \\ \text { ds DNA: } & \text { Double-strand DNA } \\ \text { ss DNA: } & \text { Single-strand DNA } \\ \text { dA: } & \text { Deoxyadenosine } \\ \text { dC: } & \text { Deoxycytidine } \\ \text { dG: } & \text { Deoxyguanosine } \\ \text { DNA: } & \text { Deoxyribonucleic acid } \\ \text { DPP: } & \text { Difference pulse polarography } \\ \text { dT: } & \text { Deoxythymidine } \\ \text { LD: } & \text { Linear dichroism } \\ \text { Wavenumber: } & \left.\text { (cm }{ }^{-1}\right) \text {. }\end{array}$

\section{Conflict of Interests}

The authors declare that there is no conflict of interests regarding the publication of this paper.

\section{Acknowledgments}

Financial support from the following Grants GAČR P304/ $11 / 2246$, IGA VFU 42/2011/FaF, and IGA VFU 43/2011/FaF is highly acknowledged.

\section{References}

[1] A. Sakunphueak and P. Panichayupakaranant, "Effects of donor plants and plant growth regulators on naphthoquinone production in root cultures of Impatiens balsamina," Plant Cell, Tissue and Organ Culture, vol. 102, no. 1, pp. 9-15, 2010.

[2] P. Babula, V. Adam, L. Havel, and R. Kizek, "Noteworthy secondary metabolites naphthoquinones-their occurrence, pharmacological properties and analysis," Current Pharmaceutical Analysis, vol. 5, no. 1, pp. 47-68, 2009.

[3] P. Babula, D. Huska, P. Hanustiak et al., "Flow injection analysis coupled with carbon electrodes as the tool for analysis of naphthoquinones with respect to their content and functions in biological samples," Sensors, vol. 6, no. 11, pp. 1466-1482, 2006.

[4] P. Babula, R. Mikelová, V. Adam et al., "Chromatographic analysis of naphthoquinones in plants," Chemicke Listy, vol. 100, no. 4, pp. 271-276, 2006.

[5] A. Emadi, A. Le, C. J. Harwood et al., "Metabolic and electrochemical mechanisms of dimeric naphthoquinones cytotoxicity in breast cancer cells," Bioorganic and Medicinal Chemistry, vol. 19, no. 23, pp. 7057-7062, 2011.

[6] A. E. Ross, A. Emadi, L. Marchionni et al., "Dimeric naphthoquinones, a novel class of compounds with prostate cancer cytotoxicity," BJU International, vol. 108, no. 3, pp. 447-454, 2011.

[7] K. Nakagawa, "New developments in research on vitamin K biosynthesis," Journal of Health Science, vol. 56, no. 6, pp. 623631, 2010. 
[8] J. Oldenburg, M. Marinova, C. Müller-Reible, and M. Watzka, "The vitamin K cycle," Vitamins and Hormones, vol. 78, pp. 3562, 2008.

[9] D. W. Stafford, “The vitamin K cycle," Journal of Thrombosis and Haemostasis, vol. 3, no. 8, pp. 1873-1878, 2005.

[10] P. Babula, V. Adam, R. Kizek, Z. Sladký, and L. Havel, "Naphthoquinones as allelochemical triggers of programmed cell death," Environmental and Experimental Botany, vol. 65, no. 2-3, pp. 330-337, 2009.

[11] B. K. Aithal, M. R. S. Kumar, B. N. Rao, N. Udupa, and B. S. S. Rao, "Juglone, a naphthoquinone from walnut, exerts cytotoxic and genotoxic effects against cultured melanoma tumor cells," Cell Biology International, vol. 33, no. 10, pp. 1039-1049, 2009.

[12] K. Gong and W. Li, "Shikonin, a Chinese plant-derived naphthoquinone, induces apoptosis in hepatocellular carcinoma cells through reactive oxygen species: a potential new treatment for hepatocellular carcinoma," Free Radical Biology and Medicine, vol. 51, no. 12, pp. 2259-2271, 2011.

[13] V. Klaus, T. Hartmann, J. Gambini et al., "1,4-Naphthoquinones as inducers of oxidative damage and stress signaling in $\mathrm{HaCaT}$ human keratinocytes," Archives of Biochemistry and Biophysics, vol. 496, no. 2, pp. 93-100, 2010.

[14] R. R. Kitagawa, C. Bonacorsi, L. M. da Fonseca, W. Vilegas, and M. S. G. Raddi, "Anti-Helicobacter pylori activity and oxidative burst inhibition by the naphthoquinone 5-methoxy3,4-dehydroxanthomegnin from Paepalanthus latipes," Revista Brasileira de Farmacognosia, vol. 22, no. 1, pp. 53-59, 2011.

[15] G. S. Levin, G. Tremasova Ya., and S. V. Kostova, "On the mechanism of action of a synthetic 1,4-naphthoquinone derivative on the respiratory chain of liver and heart mitochondria," Biokhimiya, vol. 54, no. 10, pp. 1630-1637, 1989.

[16] A. G. Medentsev, Y. A. Arinbasarova, and V. K. Akimenko, "Respiratory activity and naphthoquinone synthesis in the fungus Fusarium decemcellulare exposed to oxidative stress," Mikrobiologiya, vol. 71, no. 2, pp. 176-182, 2002.

[17] A. G. Medentsev, A. N. Maslov, and V. K. Akimenko, "Naphthoquinone metabolites of the fungi Fusarium and Verticillium: the mechanism of phytotoxic effect," Biokhimiya, vol. 55, no. 10, pp. 1766-1772, 1990.

[18] G. L. Beretta and F. Zunino, "Molecular mechanisms of anthracycline activity," in Anthracycline Chemistry and Biology II: Mode of Action, Clinical Aspects and New Drugs, vol. 283, pp. 1-19, Springer, Berlin, Germany, 2008.

[19] M. Masarik, D. Huska, V. Adam et al., "Doxorubicin and genomic DNA, new insights in drug-nucleic acids interactions," International Journal of Molecular Medicine, vol. 24, pp. S49S49, 2009.

[20] R. Prusa, D. Huska, V. Adam et al., "In vivo and in vitro electrochemical investigation of doxorubicin/ellipticine interaction with DNA," Clinical Chemistry, vol. 55, no. 6, pp. A217-A217, 2009.

[21] L. Trnkova, M. Stiborova, D. Huska et al., "Electrochemical biosensor for investigation of anticancer drugs interactions (doxorubicin and ellipticine) with DNA," in IEEE Sensors Conference (SENSORS '09), vol. 1-3, pp. 1200-1203, New York, NY, USA, October 2009.

[22] Z.-Y. Hao, Q.-W. Liu, J. Xu, L. Jia, and S.-B. Li, "Synthesis, characterization, antioxidant activities, and DNA-binding studies of (E)- $\mathrm{N}^{\prime}$-[1-(pyridin-2-yl)ethylidene] isonicotinohydrazide and its $\operatorname{Pr}(\mathrm{III})$ and $\mathrm{Nd}(\mathrm{III})$ complexes," Chemical and Pharmaceutical Bulletin, vol. 58, no. 10, pp. 1306-1312, 2010.
[23] T. M. Jovin, L. P. McIntosh, and D. J. Arndt-Jovin, "Left-handed DNA: from synthetic polymers to chromosomes," Journal of Biomolecular Structure and Dynamics, vol. 1, no. 1, pp. 21-57, 1983.

[24] N.-U. H. Khan, N. Pandya, M. Kumar et al., "Influence of chirality using $\mathrm{Mn}$ (iii) salen complexes on DNA binding and antioxidant activity," Organic and Biomolecular Chemistry, vol. 8, no. 19, pp. 4297-4307, 2010.

[25] A. M. Pizarro, A. Habtemariam, and P. J. Sadler, "Activation mechanisms for organometallic anticancer complexes," Topics in Organometallic Chemistry, vol. 32, pp. 21-56, 2010.

[26] E. F. Sachs, A. Nadler, and U. Diederichsen, "A DNA and metal binding hybrid based on triostin A," Journal of Peptide Science, vol. 16, pp. 86-86, 2010.

[27] H. A. Tajmirriahi, M. Langlais, and R. Savoie, "A comparativestudy of DNA interaction with divalent metal-ions-metalion binding-sites and DNA conformational-changes, studied by laser Raman-spectroscopy," in Metal Ions in Biology and Medicine, pp. 561-563, 1990.

[28] A. Woisard, G. V. Fazakerley, and W. Guschlbauer, "Z-DNA is formed by poly $(\mathrm{dC}-\mathrm{DG})$ and poly $(\mathrm{dm} 5 \mathrm{C}-\mathrm{dG})$ at micro or nanomolar concentrations of some zinc(II) and copper(II) complexes," Journal of Biomolecular Structure and Dynamics, vol. 2, no. 6, pp. 1205-1220, 1985.

[29] C. Zimmer and G. Luck, "Conformation and reactivity of DNA. VI. Circular dichroism studies of salt induced conformational changes of DNAs of different base composition," Biochimica et Biophysica Acta, vol. 361, no. 1, pp. 11-32, 1974.

[30] A. Brozovic, J. Damrot, R. Tsaryk et al., "Cisplatin sensitivity is related to late DNA damage processing and checkpoint control rather than to the early DNA damage response," Mutation Research-Fundamental and Molecular Mechanisms of Mutagenesis, vol. 670, no. 1-2, pp. 32-41, 2009.

[31] O. Vrána, V. Mašek, V. Dražan, and V. Brabec, "Raman spectroscopy of DNA modified by intrastrand cross-links of antitumor cisplatin," Journal of Structural Biology, vol. 159, no. 1, pp. 1-8, 2007.

[32] R. Zhang, Y. Niu, and Y. Zhou, "Increase the cisplatin cytotoxicity and cisplatin-induced DNA damage in HepG2 cells by XRCC1 abrogation related mechanisms," Toxicology Letters, vol. 192, no. 2, pp. 108-114, 2010.

[33] V. Brabec, O. Vrana, and V. Boudny, "Superhelical torsion controls DNA interstrand cross-linking by antitumor cisplatin," Progress in Biophysics and Molecular Biology, vol. 65, pp. PB113PB113, 1996.

[34] Y. Katsuda, Y. Yoshikawa, T. Sato et al., "Cisplatin and its analogues induce a significant change in the higher-order structure of long duplex DNA," Chemical Physics Letters, vol. 473, no. 1-3, pp. 155-159, 2009.

[35] H. Wermann, H. Stoop, A. J. M. Gillis et al., "Global DNA methylation in fetal human germ cells and germ cell tumours: association with differentiation and cisplatin resistance," Journal of Pathology, vol. 221, no. 4, pp. 433-442, 2010.

[36] J. J. Yu, X. B. Liang, Q. W. Yan et al., "CHK2 and ERCC1 in the DNA adduct repair pathway that mediates acquired cisplatin resistance," in Platinum and Other Heavy Metal Compounds in Cancer Chemotherapy-Molecular Mechanisms and Clinical Applications, pp. 189-194, Humana Press, Totowa, NJ, USA, 2009. 
[37] M. N. da Silva, V. F. Ferreira, and M. C. B. V. De Souza, "An overview of the chemistry and pharmacology of naphthoquinones with emphasis on $\beta$-Lapachone and derivatives," Quimica Nova, vol. 26, no. 3, pp. 407-416, 2003.

[38] C. Wei, G. Jia, J. Yuan, Z. Feng, and C. Li, "A spectroscopic study on the interactions of porphyrin with G-quadruplex DNAs," Biochemistry, vol. 45, no. 21, pp. 6681-6691, 2006.

[39] A. Kawiak, A. Królicka, and E. Łojkowska, "In vitro cultures of Drosera aliciae as a source of a cytotoxic naphthoquinone: ramentaceone," Biotechnology Letters, vol. 33, no. 11, pp. 23092316, 2011.

[40] K. N. Kontogiannopoulos, A. N. Assimopoulou, K. Dimas, and V. P. Papageorgiou, "Shikonin-loaded liposomes as a new drug delivery system: physicochemical characterization and in vitro cytotoxicity," European Journal of Lipid Science and Technology, vol. 113, no. 9, pp. 1113-1123, 2011.

[41] R. R. Kitagawa, W. Vilegas, I. Z. Carlos, and M. S. G. Raddi, "Antitumor and immunomodulatory effects of the naphthoquinone 5-methoxy-3,4-dehydroxanthomegnin," Revista Brasileira de Farmacognosia, vol. 21, no. 6, pp. 1084-1088, 2011.

[42] Z. F. Plyta, T. Li, V. P. Papageorgiou et al., "Inhibition of topoisomerase I by naphthoquinone derivatives," Bioorganic and Medicinal Chemistry Letters, vol. 8, no. 23, pp. 3385-3390, 1998.

[43] P. Babula, J. Vanco, L. Krejcova et al., "Voltammetric characterization of Lawsone-Copper(II) ternary complexes and their interactions with dsDNA," International Journal of Electrochemical Science, vol. 7, no. 8, pp. 7349-7366, 2012.

[44] A. Bulovas, N. Dirvianskyte, Z. Talaikyte et al., "Electrochemical and structural properties of self-assembled monolayers of 2-methyl-3-( $\omega$-mercaptoalkyl)-1,4-naphthoquinones on gold," Journal of Electroanalytical Chemistry, vol. 591, no. 2, pp. 175188, 2006.

[45] D. Sajan, K. P. Laladhas, I. Hubert Joe, and V. S. Jayakumar, "Vibrational spectra and density functional theoretical calculations on the antitumor drug, plumbagin," Journal of Raman Spectroscopy, vol. 36, no. 10, pp. 1001-1011, 2005.

[46] C. E. M. Carvalho, I. M. Brinn, A. V. Pinto, and M. D. C. F. R. Pinto, "Fluorescent symmetric phenazines from naphthoquinones 3. Steady-state spectroscopy and solvent effect of seven phenazine derivatives: structure-photophysics correlations," Journal of Photochemistry and Photobiology A, vol. 136, no. 1-2, pp. 25-33, 2000.

[47] C. E. M. Carvalho, N. C. de Lucas, J. O. M. Herrera, A. V. Pinto, M. C. F. R. Pinto, and I. M. Brinn, "Fluorescent symmetric phenazines from naphthoquinones 4 . Solvent effect on time-resolved fluorescence," Journal of Photochemistry and Photobiology A, vol. 167, no. 1, pp. 1-9, 2004.

[48] G. Balakrishnan, A. Babaei, A. J. McQuillan, and S. Umapathy, "Resonance Raman and infrared spectral studies on radical anions of model photosynthetic reaction center quinones (naphthoquinone derivatives)," Journal of Biomolecular Structure and Dynamics, vol. 16, no. 1, pp. 123-131, 1998.

[49] J.-R. Burie, A. Boussac, C. Boullais et al., "FTIR spectroscopy of UV-generated quinone radicals: evidence for an intramolecular hydrogen atom transfer in ubiquinone, naphthoquinone, and plastoquinone," Journal of Physical Chemistry, vol. 99, no. 12, pp. 4059-4070, 1995.

[50] M. Kažemekaite, V. Railaite, A. Bulovas et al., "Synthesis, self-assembling and redox properties of 2-[( $\omega$-sulfanylalkyl)amino]-1,4-naphthoquinones," Collection of Czechoslovak Chemical Communications, vol. 71, no. 9, pp. 1383-1391, 2006.
[51] M. Umadevi, A. Ramasubbu, P. Vanelle, and V. Ramakrishnan, "Spectral investigations on 2-methyl-1,4-naphthoquinone: solvent effects, host-guest interactions and SERS," Journal of Raman Spectroscopy, vol. 34, no. 2, pp. 112-120, 2003.

[52] N. Leopold and B. Lendl, "A new method for fast preparation of highly surface-enhanced raman scattering (SERS) active silver colloids at room temperature by reduction of silver nitrate with hydroxylamine hydrochloride," Journal of Physical Chemistry B, vol. 107 , no. 24 , pp. 5723-5727, 2003.

[53] C. H. Munro, W. E. Smith, M. Garner, J. Clarkson, and P. C. White, "Characterization of the surface of a citrate-reduced colloid optimized for use as a substrate for surface-enhanced resonance raman scattering," Langmuir, vol. 11, no. 10, pp. 37123720, 1995.

[54] B. Prescott, W. Steinmetz, and G. J. Thomas Jr., "Characterization of DNA structures by laser Raman spectroscopy," Biopolymers, vol. 23, no. 2, pp. 235-256, 1984.

[55] A. Rodger, "Linear dichroism," Methods in Enzymology, vol. 226, pp. 232-258, 1993.

[56] T. Bugarcic, O. Nováková, A. Halámiková et al., "Cytotoxicity, cellular uptake, and DNA interactions of new monodentate ruthenium(II) complexes containing terphenyl arenes," Journal of Medicinal Chemistry, vol. 51, no. 17, pp. 5310-5319, 2008.

[57] L. Dalla Via, O. Gia, S. M. Magno, A. Dolmella, D. Marton, and V. Di Noto, "Synthesis, characterization and biological activity of platinum(II) complexes with l- and d-ornithine ligands," Inorganica Chimica Acta, vol. 359, no. 13, pp. 4197-4206, 2006.

[58] L. Giovagnini, C. Marzano, F. Bettio, and D. Fregona, "Mixed complexes of $\mathrm{Pt}(\mathrm{II})$ and $\mathrm{Pd}(\mathrm{II})$ with ethylsarcosinedithiocarbamate and 2-/3-picoline as antitumor agents," Journal of Inorganic Biochemistry, vol. 99, no. 11, pp. 2139-2150, 2005.

[59] R. Žaludová, G. Natile, and V. Brabec, "The effect of antitumor trans-[PtCl2(E-iminoether)2] on $\mathrm{B} \rightarrow \mathrm{Z}$ transition in DNA," Anti-Cancer Drug Design, vol. 12, no. 4, pp. 295-309, 1997.

[60] J. Duguid, V. A. Bloomfield, J. Benevides, and G. J. Thomas Jr., "Raman spectroscopy of DNA-metal complexes. I. Interactions and conformational effects of the divalent cations: $\mathrm{Mg}, \mathrm{Ca}, \mathrm{Sr}$, $\mathrm{Ba}, \mathrm{Mn}, \mathrm{Co}, \mathrm{Ni}, \mathrm{Cu}, \mathrm{Pd}$, and Cd," Biophysical Journal, vol. 65, no. 5, pp. 1916-1928, 1993.

[61] L. G. Marzilli, J. S. Saad, Z. Kuklenyik, K. A. Keating, and Y. Xu, "Relationship of solution and protein-bound structures of DNA duplexes with the major intrastrand cross-link lesions formed on cisplatin binding to DNA," Journal of the American Chemical Society, vol. 123, no. 12, pp. 2764-2770, 2001.

[62] D. Serban, J. M. Benevides, and G. J. Thomas Jr., "DNA secondary structure and Raman markers of supercoiling in Escherichia coli plasmid pUC19," Biochemistry, vol. 41, no. 3, pp. 847-853, 2002.

[63] J. M. Benevides, J. Kawakami, and G. J. Thomas Jr., "Mechanisms of drug-DNA recognition distinguished by Raman spectroscopy," Journal of Raman Spectroscopy, vol. 39, no. 11, pp. $1627-1634,2008$.

[64] J. M. Benevides, S. A. Overman, and G. J. Thomas Jr., "Raman, polarized Raman and ultraviolet resonance Raman spectroscopy of nucleic acids and their complexes," Journal of Raman Spectroscopy, vol. 36, no. 4, pp. 279-299, 2005.

[65] H. Deng, V. A. Bloomfield, J. M. Benevides, and G. J. Thomas, "Dependence of the raman signature of genomic B-DNA on nucleotide base sequence," Biopolymers, vol. 50, no. 6, pp. 656666, 1999.

[66] J. G. Duguid, V. A. Bloomfield, J. M. Benevides, and G. J. Thomas Jr., "Raman spectroscopy of DNA-metal complexes. II. 
The thermal denaturation of DNA in the presence of $\mathrm{Sr}^{2+}, \mathrm{Ba}^{2+}$, $\mathrm{Mg}^{2+}, \mathrm{Ca}^{2+}, \mathrm{Mn}^{2+}, \mathrm{Co}^{2+}, \mathrm{Ni}^{2+}$, and $\mathrm{Cd}^{2+}$, Biophysical Journal, vol. 69, no. 6, pp. 2623-2641, 1995.

[67] J. G. Duguid, V. A. Bloomfield, J. M. Benevides, and G. J. Thomas Jr., "DNA melting investigated by differential scanning calorimetry and Raman spectroscopy," Biophysical Journal, vol. 71, no. 6, pp. 3350-3360, 1996.

[68] C. I. Morari and C. M. Muntean, "Numerical simulations of Raman spectra of guanine-cytosine Watson-Crick and protonated Hoogsteen base pairs," Biopolymers, vol. 72, no. 5, pp. 339344, 2003.

[69] C. M. Muntean and I. Bratu, "Raman spectroscopic study on the subpicosecond dynamics in calf-thymus DNA, upon lowering the $\mathrm{pH}$ and in the presence of $\mathrm{Mn}^{2+}$ ions," Spectroscopy, vol. 22, no. 6, pp. 475-489, 2008.

[70] C. M. Muntean, L. Dostál, R. Misselwitz, and H. Welfle, "DNA structure at low $\mathrm{pH}$ values, in the presence of $\mathrm{Mn}^{2+}$ ions: a Raman study," Journal of Raman Spectroscopy, vol. 36, no. 11, pp. 1047-1051, 2005.

[71] C. M. Muntean and G. M. J. Segers-Nolten, "Raman microspectroscopic study of effects of $\mathrm{Na}(\mathrm{I})$ and $\mathrm{Mg}(\mathrm{II})$ ions on low $\mathrm{pH}$ induced DNA structural changes," Biopolymers, vol. 72, no. 4, pp. 225-229, 2003.

[72] W. L. Peticolas, Z. Dai, and G. A. Thomas, "The use of Raman spectroscopy to characterize double $\mathrm{B} / \mathrm{Z}$ conformational junctions in DNA," Journal of Molecular Structure, vol. 242, pp. 135141, 1991.

[73] C. Rajani, J. R. Kincaid, and D. H. Petering, "The presence of two modes of binding to calf thymus DNA by metal-free bleomycin: a low frequency Raman study," Biopolymers, vol. 52, no. 3, pp. 129-146, 1999.

[74] M. Schmitt and J. Popp, "Raman spectroscopy at the beginning of the twenty-first century," Journal of Raman Spectroscopy, vol. 37, no. 1-3, pp. 20-28, 2006.

[75] E. M. Evertsz, G. A. Thomas, and W. L. Peticolas, "Raman spectroscopic studies of the DNA Crobinding site conformation, free and bound to cro protein," Biochemistry, vol. 30, no. 4, pp. 1149-1155, 1991.

[76] V. M. Dadarlat and V. K. Saxena, "Stability of triple-helical poly(dT)-poly(dA)-poly(dT) DNA with counterions," Biophysical Journal, vol. 75, no. 1, pp. 70-91, 1998.

[77] P. Gróf, D. Aslanian, and G. Rontó, “Changes of phage T7 nucleoprotein structure at low ionic strength. A Raman spectroscopic study," Biochimica et Biophysica Acta, vol. 1289, no. 1, pp. 95-104, 1996.

[78] C. M. Muntean, G. J. Puppels, J. Greve, G. M. J. Segers-Nolten, and S. Cinta-Pinzaru, "Raman microspectroscopic study on low-pH-induced DNA structural transitions in the presence of magnesium ions," Journal of Raman Spectroscopy, vol. 33, no. 10, pp. 784-788, 2002.

[79] K. L. Aubrey, S. R. Casjens, and G. J. Thomas Jr., "Secondary structure and interactions of the packaged dsDNA genome of bacteriophage P22 investigated by Raman difference spectroscopy," Biochemistry, vol. 31, no. 47, pp. 11835-11842, 1992.

[80] C. M. Muntean and I. Bratu, "Molecular relaxation processes in calf-thymus DNA, in the presence of $\mathrm{Mn}^{2+}$ and $\mathrm{Na}^{+}$ions: a Raman spectroscopic study," Spectroscopy, vol. 22, no. 5, pp. 345-359, 2008.

[81] J. Stangret and R. Savoie, "Vibrational spectroscopic study of the interaction of metal ions with diethyl phosphate, a model for biological systems," Canadian Journal of Chemistry, vol. 70, no. 12, pp. 2875-2883, 1992.
[82] S. Mukherjee and D. Bhattacharyya, "Effect of phosphorothioate chirality on the grooves of DNA double helices: a molecular dynamics study," Biopolymers, vol. 73, no. 2, pp. 269-282, 2004.

[83] M. Shanmugasundaram and M. Puranik, "Computational prediction of vibrational spectra of normal and modified DNA nucleobases," Journal of Raman Spectroscopy, vol. 40, no. 12, pp. 1726-1748, 2009.

[84] J. Qi, B. Liu, Y. Li, D. Wu, and W. Tang, "Raman spectroscopic study on Hela cells irradiated by X rays of different doses," Chinese Optics Letters, vol. 7, no. 8, pp. 734-737, 2009.

[85] D. Lin, J. Lin, Y. Wu et al., "Investigation on the interactions of lymphoma cells with paclitaxel by Raman spectroscopy," Spectroscopy, vol. 25, no. 1, pp. 23-32, 2011.

[86] A. Gfrorer, M. E. Schnetter, J. Wolfrum, and K. O. Greulich, "Double and triple helices of nucleic-acid polymers, studied by Uv-resonance Raman-spectroscopy," Berichte der Bunsengesellschaft für Physikalische Chemie, vol. 97, no. 2, pp. 155-162, 1993.

[87] C. Krafft, W. Hinrichs, P. Orth, W. Saenger, and H. Welfle, "Interaction of Tet repressor with operator DNA and with tetracycline studied by infrared and Raman spectroscopy," Biophysical Journal, vol. 74, no. 1, pp. 63-71, 1998.

[88] L. Movileanu, J. M. Benevides, and G. J. Thomas Jr., “Temperature dependence of the Raman spectrum of DNA. Part I-Raman signatures of premelting and melting transitions of Poly(dA-dT) · poly(dA-dT)," Journal of Raman Spectroscopy, vol. 30, no. 8, pp. 637-649, 1999.

[89] C. M. Muntean and I. Bratu, "Molecular dynamics in calfthymus DNA, at neutral and low $\mathrm{pH}$, in the presence of $\mathrm{Na}^{+}, \mathrm{Ca}^{2+}$ and $\mathrm{Mg}^{2+}$ ions: a Raman microspectroscopic study," Spectroscopy, vol. 21, no. 4, pp. 193-204, 2007.

[90] C. M. Muntean, K. Nalpantidis, I. Feldmann, and V. Deckert, " $\mathrm{Zn}^{2+}$-DNA interactions in aqueous systems: a Raman spectroscopic study," Spectroscopy, vol. 23, no. 3-4, pp. 155-163, 2009.

[91] A. Toyama, A. Matsubuchi, N. Fujimoto, and H. Takeuchi, "Isotope-edited UV Raman spectroscopy of protein-DNA interactions: binding modes of cyclic AMP receptor protein to a natural DNA recognition site," Journal of Raman Spectroscopy, vol. 36, no. 4, pp. 300-306, 2005.

[92] R. M. Clement, J. Sturm, and M. P. Daune, "Interaction of metallic cations with DNA. VI. Specific binding of $\mathrm{Mg}^{++}$and $\mathrm{Mn}^{++}$," Biopolymers, vol. 12, no. 2, pp. 405-421, 1973.

[93] N. Iyandurai and R. Sarojini, "Selenomethionine induced changes on the binding of spermine with DNA: a study by Fourier transform Raman and Fourier Transform infra red spectroscopy," International Journal of Pharmacology, vol. 5, no. 2, pp. 126-136, 2009.

[94] I. Notingher, S. Verrier, H. Romanska, A. E. Bishop, J. M. Polak, and L. L. Hench, "In situ characterisation of living cells by Raman spectroscopy," Spectroscopy, vol. 16, no. 2, pp. 43-51, 2002.

[95] H. Yao, Z. Tao, M. Ai et al., "Raman spectroscopic analysis of apoptosis of single human gastric cancer cells," Vibrational Spectroscopy, vol. 50, no. 2, pp. 193-197, 2009. 

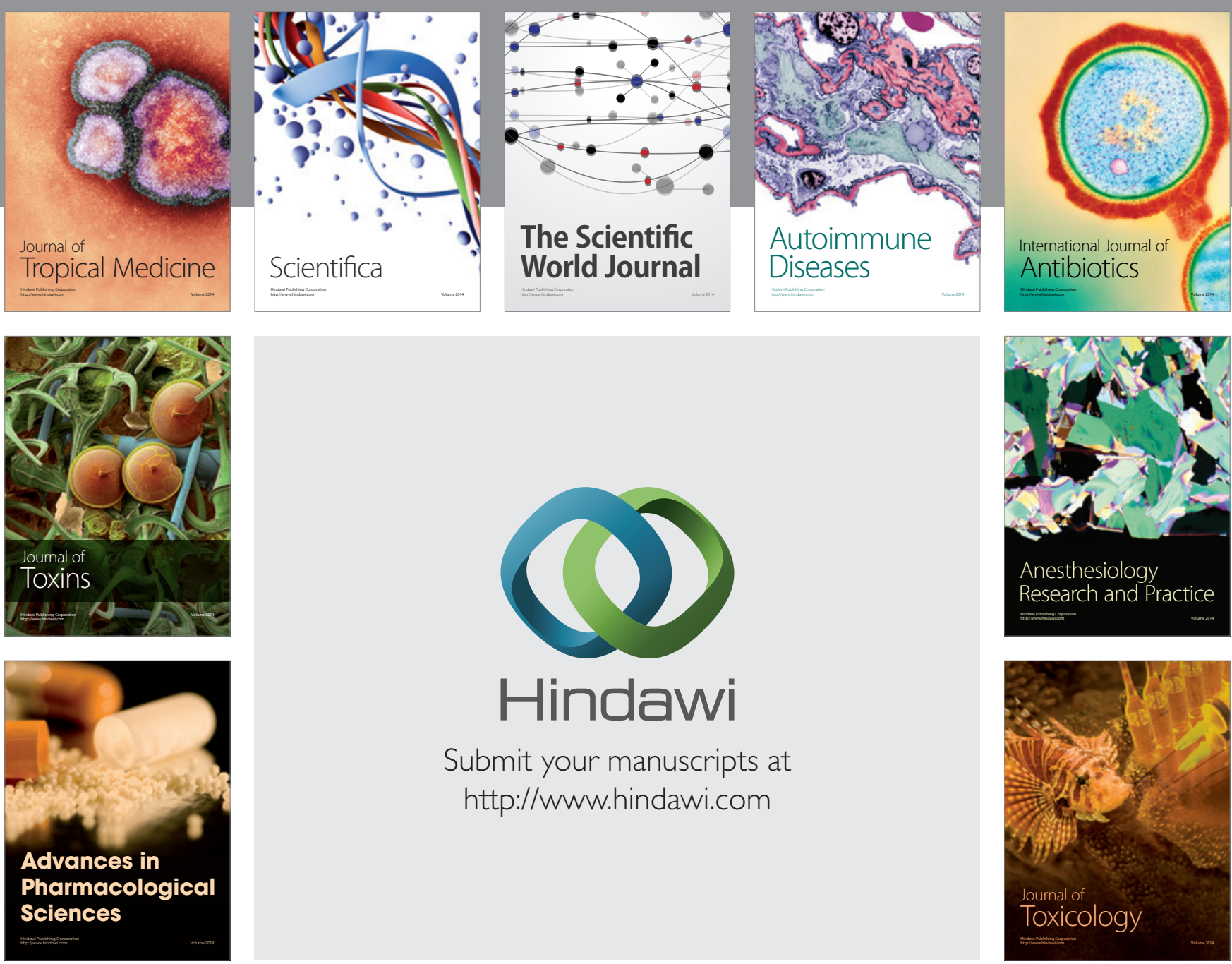

\section{Hindawi}

Submit your manuscripts at

http://www.hindawi.com
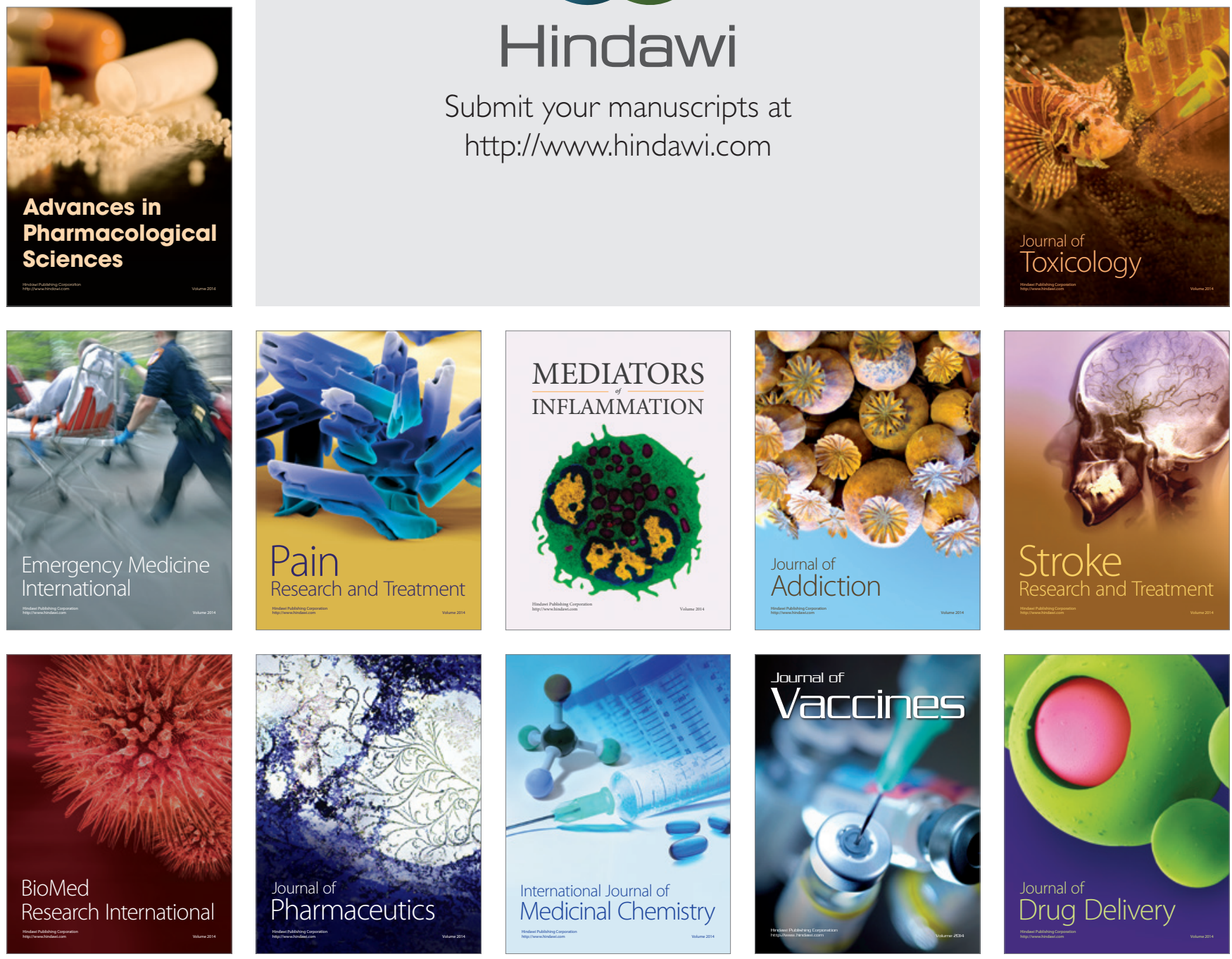